\title{
The Social Dimension of EU State Aid Law and Policy
}

\author{
Delia FERRI \\ National University of Ireland Maynooth \\ Juan Jorge PIERNAS LÓPEZ \\ University of Murcia*
}

\begin{abstract}
Traditionally, EU state aid law has been attached to the goals of maintaining free competition and preventing the distortionary effects of Member States' economic intervention, while social considerations have been considered immaterial to state aid control. However, in more recent years, EU state aid law has acquired a clearer 'social dimension', indirectly streamlining national subsidies towards social goals. The entry into force of the Treaty of Lisbon, and particularly of Articles 3(3) TEU and 9 TFEU, has had an impact on the way in which social goals have been taken into account in the application of the state aid provisions. In the last decade, the European Commission has sought out a more appropriate balance between the main objective of preserving competition in the internal market on the one hand, and social objectives, also enshrined nowadays in the Treaties, on the other. This 'social dimension' is still underdeveloped, but emerges to varying degrees when looking respectively at the definition of state aid under Article 107(1) TFEU, at the scope of the derogations under Articles 107(2) and 107(3) TFEU and at the secondary legislation adopted for their implementation.
\end{abstract}

Keywords: state aid, social policy, social justice, undertaking, selectivity, derogations, General Block Exemption Regulation (GBER)

\section{INTRODUCTION}

The Treaty of Lisbon has inserted into the EU constitutional framework a "new language in relation to social protection and social inclusion' in an attempt to rebalance market and non-market values. ${ }^{1}$ The EU recast itself as a 'highly competitive social

* This article is the product of a joint reflection. However, Sections I, II, III.A, and IV have been written by Delia Ferri, while Sections III.B, III.C, and III.D have been written by Juan Jorge Piernas López. Section V has been written jointly. We would like to thank Professor KA Armstrong and the anonymous reviewers for their comments on the earlier drafts. The usual disclaimers apply. This article builds upon and develops the chapter D Ferri and JJ Piernas Lopez, 'State Aid Law in a Social Market Economy' in D Ferri and F Cortese, The EU Social Market Economy and the Law: Theoretical Perspectives and Practical Challenges for the EU (Routledge, 2018).

1 M Dawson and B De Witte, 'Welfare Policy and Social Inclusion' in A Arnull and D Chalmers (eds), The Oxford Handbook of European Union Law (Oxford University Press, 2015), p 964. 
market economy' through Article 3(3) of the Treaty on European Union ('TEU'). Within this provision are the Union-level objectives to strive towards 'the sustainable development of Europe based on balanced economic growth' and 'social progress'. Article 3(3) also provides that the EU must 'combat social exclusion and discrimination, and [...] promote social justice'. Moreover, Article 9 of the Treaty on the Functioning of the European Union ('TFEU') creates further linkages between the internal market and socially oriented values, by stating that '[i]n defining and implementing its policies and activities, the Union shall take into account requirements linked to the promotion of a high level of employment, the guarantee of adequate social protection, the fight against social exclusion, and a high level of education, training and protection of human health'. Articles 3(3) TEU and 9 TFEU, read in light of Article 2 TEU, seem to support the mainstreaming of social considerations and pay tribute to the need for economic activities to serve the common social good in a more tangible manner. However, these constitutional innovations have not altered the very limited scope of the EU social policy, and the-still constrained-Union competence in this domain. The EU can only coordinate social policies and social laws of the Member States. ${ }^{2}$

The renewed commitment to move beyond those market paradigms that had characterised the pre-Lisbon constitutional framework has, however, gone hand in hand with the 'displacement' of 'Social Europe', as it has been evocatively termed. ${ }^{3}$ On the one hand, no new legislation has been adopted in those fields covered by the TFEU provisions on 'Social Policy', 4 and social issues have been mostly addressed either through soft law instruments or soft governance processes (such as the Open Method of Coordination). On the other hand, this 'displacement' has translated into the embedding of socially minded provisions into market regulations. Social goals have, hence, become more visible across various forms and areas of EU intervention. ${ }^{5}$ Moreover, in some strands of internal market legislation, such as public

\footnotetext{
2 These socially driven interpretative clauses are well-rooted in the Treaties. The Treaty Establishing the European Economic Community ('EEC Treaty'), for example, already mentioned social goals, such as: 'to promote throughout the Community a harmonious development of economic activities, a continuous and balanced expansion, an increase in stability, an accelerated raising of the standard of living and closer relations between the States belonging to it', and 'to promote improved working conditions and an improved standard of living for workers, so as to make possible their harmonization while the improvement is being maintained'. Both the Treaty of Maastricht and the Treaty of Amsterdam extended these social ideals even further, without enhancing the quite modest EU social policy. On this issue, see CE O'Sullivan, 'The EU between Market State Ideals and Social Market Economy Objectives: Placing the Social Market Economy within the Union's Constitutional History' in D Ferri and F Cortese, The EU Social Market Economy and the Law (Routledge, 2018), p 17.

3 C Kilpatrick, 'The Displacement of Social Europe: A Productive Lens of Inquiry' (2018) 14 European Constitutional Law Review 62.

${ }^{4}$ For the most part, legislation in this field dates back to the pre-Amsterdam period and has, at best, been recast in the early 2000s. See E Muir, 'Drawing Positive Lessons from the Presence of "The Social” Outside of EU Social Policy' (2018) 14 European Constitutional Law Review 75.

5 Most recently, ibid.
} 
procurement law, ${ }^{6}$ social objectives are bonded with economic goals. The juxtaposition of economic and social goals, most likely in the hope of facilitating a convergence between them, has, however, revamped (instead of soothed) the debate on the 'embedded liberalism' of the EU. ${ }^{7}$ Questions around the level at which social policy ought to be governed (national or EU?) and around the progressive erosion of national welfare states through the enforcement of the economic freedoms remain hotly debated. New questions have also emerged concerning the extent to which the EU strikes a balance, as Garben puts it, between the 'market' and the 'social'. 8

This article aims to contribute to the debate by looking at EU state aid law and policy. This is a field traditionally considered to be part of EU competition law and characterised by an inherent internal market dimension, ${ }^{9}$ but intersects with areas considered to be politically or socially sensitive for the Member States, including taxation and public services. For this reason, it represents an interesting test-bed to assess the influence of these socially oriented provisions and to identify the extent to which the EU has reconciled Union market-based objectives with social goals and non-market values. This article explores whether the entry into force of the Treaty of Lisbon and the mainstreaming of social considerations has had an impact on the way in which social goals have been taken into account in the application of the state aid provisions. It argues that, in the post-Lisbon era, a twofold 'social dimension' of EU state aid law and policy has slowly emerged. On one hand, the interpretation of the notion of aid by the Commission and by the Court of Justice ('CJEU') has carved out a wider space for Member States to pursue social goals without triggering the prohibition of Article 107(1) TFEU. By tightening the scope of application of EU state rules, the Commission has allowed Member States to subsidise a range of educational, health, and cultural activities within the scope of their own welfare policies. On the other hand, perhaps more interestingly, in applying state aid rules, the

6 S Aerosmith and P Kunzlik, Social and Environmental Policies in EC Procurement Law: New Directives and New Directions (Cambridge University Press, 2009); B Sjåfjell and A Wiesbrock, Sustainable Public Procurement under EU Law (Cambridge University Press, 2016). For a critical analysis, see C Bovis, 'The Social Dimension of EU Public Procurement and the "Social Market Economy" in Ferri and Cortese, note 2 above.

7 The concept of 'embedded liberalism' was elaborated by Ruggie in his discussion of the global economic order (JG Ruggie, 'International Regimes, Transactions, and Change: Embedded Liberalism in the Postwar Economic Order' (1982) 36 International Organization 379), and it has then been used to refer to the neoliberal attitude of EU polices. See D Ashiagbor, 'Unravelling the Embedded Liberal Bargain: Labour and Social Welfare Law in the Context of EU Market Integration' (2013) 19 European Law Journal 303. C O'Brien, 'Reflections of an Outlier' (2016) 20 European University Institute Working Papers 29 quite powerfully argues that the EU 'ethos has become gradually harder to distinguish from that of the faceless, naturalised wisdom of global markets'.

8 S Garben, "The Constitutional (Im)balance between "the Market" and "the Social" in the European Union' (2017) 13(1) European Constitutional Law Review 23-61. See also S Garben, 'The European Pillar of Social Rights: An Assessment of its Meaning and Significance' (2019) 21 Cambridge Yearbook of European Legal Studies.

9 Inter alia Matra v Commission, C-225/91, EU:C:1993:239. See also JL Buendía Sierra, 'Not Like This: Some Skeptical Remarks on the "Refined Economic Approach" in State Aid' (2006) Proceedings of 4th EStALI Expert's Forum on New Developments in European State Aid Law. 
Commission has developed its own vision of 'good' state aid policy, de facto aligning national state aid policies with the EU social goals. This is visible in the application of Article 107(2)(a) TFEU on aid having 'a social character', in the assessment of schemes under Article 107(3) TFEU, and in the General Block Exemption Regulation ('GBER'), which will be discussed in turn. Particularly, it is significant that the Commission has often framed its own assessment in the broader context of the Europe 2020 strategy, which is repeatedly cited, and has referred to social goals explicitly identified in other policy documents.

After this brief introduction, the remainder of this article is structured as follows. Section II sets the scene and introduces the role of EU state aid law within the Treaties. Section III examines the extent to which social considerations have come into play in the definition of state aid under Article 107(1) TFEU. Section IV discusses whether and to what extent social considerations may lead to an aid measure being compatible with the internal market under the derogations provided by the Treaty and secondary legislation, in particular, the Commission Regulation (EU) 651/2014, better known as the GBER. ${ }^{10}$ Section $\mathrm{V}$ presents some conclusions and suggests that there has been a distinct shift in the Commission's approach to state aid after the entry into force of the Treaty of Lisbon. In particular, social goals have been become more evident and steadily mainstreamed within the compatibility assessment.

\section{STATE AID LAW IN THE TREATIES}

State aid control was inserted in the Treaty founding the European Economic Community ('EEC Treaty') with the intention of maintaining a level playing field for undertakings, to support the creation and functioning of the internal market. ${ }^{11}$ It was a pragmatic addition of the Rome Treaties based on the experience of the European Coal and Steel Community under the Paris Treaty of 1951 that had introduced a total ban of aids under Article 4(c), which was largely disregarded. ${ }^{12}$

It is well known that Article 107(1) TFEU provides that any aid granted by a Member State or through State resources, which distorts, or threatens to distort, competition by favouring certain undertakings or the production of certain goods, is incompatible with the internal market, insofar as it affects trade between the Member States. Article 107(1) does not define what an aid is, but the CJEU has clarified that the notion of aid requires the following criteria to be met. ${ }^{13}$ First, there must

\footnotetext{
10 Commission Regulation (EU) 651/2014 of 17 June 2014 declaring certain categories of aid compatible with the internal market in application of Articles 107 and 108 of the Treaty Text with EEA relevance. [2014] OJ L187/1.

11 JJ Piernas López, The Concept of State Aid under EU Law. From Internal Market to Competition and Beyond (Oxford University Press, 2015), p 11.

12 C Ehlermann, 'State Aid Control in the European Union: Success or Failure?' (1994) 18 Fordham International Law Journal 1212, p 1216.

13 For a summary of the main case law concerning the criteria of Article 107(1) TFEU, see European Commission, 'Notice on the Notion of State Aid as Referred to in Article 107(1) of the Treaty on the Functioning of the European Union', [2016] OJ C262/1.
} 
be an intervention by the State or through State resources. Second, the intervention must be liable to affect trade between Member States. Third, it must confer an advantage on the recipient. The CJEU has also clarified that the advantage conferred must be selective, as it has to favour 'certain undertakings or the production of certain goods'. ${ }^{14}$ Measures of general application, directed to all undertakings in fact do not give rise to state aid. Fourth, the intervention must distort or threaten to distort competition. $^{15}$

The blanket prohibition of Article 107(1) TFEU, however, is allayed by a set of exceptions laid down in Article 107(2) and (3) TFEU. These exceptions are premised on the assumption that markets are not entirely self-regulating, and do not always work properly if left alone. Consequently, some intervention from the State may be needed for markets to work more effectively. In addition, equity and social considerations may call for public intervention. As noted most recently by Hussein and Lyons, the Treaty seeks to achieve a balance between an EU-liberalised and -integrated market and Member States' prerogatives to intervene in their own economies. $^{16}$

The EU's Treaty architecture of state aid is based on a system of ex ante authorisation by the European Commission. This means that state aids are prohibited unless the Commission has been notified of the aid, has assessed it under the scope of Article 107(2) or (3) TFEU, and has finally approved it, in compliance with Article 108 TFEU. Aid falling under the de jure derogations set forth in Article 107(2) TFEU must be considered compatible with the internal market. By contrast, the Commission may authorise aids under Article 107(3) TFEU, and case law has repeatedly stated that this provision must be interpreted strictly. ${ }^{17}$ However, it is commonly acknowledged that the Commission has significant discretion in carrying out an assessment of economic, technical, and policy considerations, and has quite a wide leeway when evaluating whether the aid is appropriate (and proportionate) to achieve the goals enshrined in Article 107(3) TFEU. To increase the degree of legal certainty in the assessment under Article 107(3) TFEU, and in an effort to identify common principles for evaluating the compatibility of an aid with the internal market, the Commission has adopted various guidelines, mainly in the form of 'communications'. These guidelines have also reinforced the Commission's position vis-à-vis the Member States, as the guidelines and communications are binding on the Commission by virtue of the case law of the Union Courts.

Article 109 TFEU allows for the adoption of secondary legislation in the field of state aid. Under this provision, the Council adopted Regulation 994/98, then superseded by Regulation 2015/1588, ${ }^{18}$ both of which empowered the Commission to

\footnotetext{
14 Inter alia Spain v Commission, C-409/00, EU:C:2003:92.

15 Altmark, C-280/00, EU:C:2003:415, para 75.

16 K Hussein and B Lyons, 'The New Political Economy of EU State Aid Policy' (2013) 13 Journal of Industry, Competition and Trade 1.

17 Among others, Philip Morris, 730/79, EU:C:1980:209.

18 Council Regulation (EC) 994/98 [1998] OJ L142/1. This regulation was repealed by Council Regulation (EU) 2015/1588 of 13 July 2015 on the application of Articles 107 and 108 of the Treaty
} 
adopt individual regulations declaring certain types of aid to be lawful, and exempting them from the obligation of prior notification. Besides the De minimis Regulation, ${ }^{19}$ the Commission also endorsed a series of exemption regulations, ${ }^{20}$ consolidated in the $2008 \mathrm{GBER}^{21}$ which was subsequently replaced by a new GBER in 2014. ${ }^{22}$ The GBER lays down the conditions under which several types of aid can be considered compatible with the internal market, and exempted from prior notification.

\section{BALANCING THE 'MARKET' AND THE 'SOCIAL' IN THE NOTION OF AID}

While economic freedoms and internal market legislation have progressively expanded their scope of application to erode the Member States' regulatory capacity in social policy areas, provoking the 'asymmetry' evoked by Fritz Scharpf, ${ }^{23}$ EU state aid law seems to show a relatively different-albeit not opposite- trend. In the last few years, the EU has attempted to reconcile 'the market' and 'the social' by 'narrowing' the scope of application of EU state rules, allowing Member States to pursue their own welfare policies. Although there is no apparent room for any social consideration under Article 107(1) TFEU, social goals pursued by national measures have in fact come into play when assessing whether or not the measure constituted an aid. Those goals have, to varying degrees, become relevant in the way in which four concepts embedded in the notion of aid have been interpreted, namely those of 'undertaking', 'selectivity', 'advantage', and 'effect on trade'.

\section{A. The 'creeping social' in the notion of undertaking}

It is well known that, just like with the other competition law rules, ${ }^{24}$ state aid provisions only apply where the beneficiary of a measure is an 'undertaking', 25 ie an entity

\footnotetext{
(F'note continued)

on the Functioning of the European Union to certain categories of horizontal state aid. OJ L248, 24.9.2015, pp 1-8. A new proposal to amend the latter regulation has been presented by the Commission in June 2018 (COM (2018) 398 final).

19 Commission Regulation (EC) 1407/2013 [2013] OJ L352/1.

${ }^{20}$ Commission Regulations (EC) 68/2001 [2001] OJ L10/20, 70/2001 [2001] OJ L10/33, 2204/2001 [2002] OJ L337/3, and 1628/2006 [2006] OJ L32/29.

21 Commission Regulation (EC) 800/2008 [2008] OJ L214/3, amended by Commission Regulation (EU) 1224/2013 [2013] OJ L320/2.

22 Commission Regulation (EU) 651/2014 [2014] OJ L187/1.

23 F Scharpf, 'The Asymmetry of European Integration, or Why the EU Cannot Be a "Social Market Economy"' (2010) 8(2) Socio-economic Review 211.

24 In this respect, see K Armstrong, Governing Social Inclusion: Europeanization through Policy Coordination (Oxford University Press, 2011), pp 196 et seq.

25 Among others, see Enirisorse, C-237/04, EU:C:2006:197, paras 27-28. There is, however, a third 'lieu' where the ordinary application of the state aid rules has been excluded under Article 106(2) TFEU: Services of General Economic Interest (SGEI). The CJEU has been sensible with regard to financial
} 
engaged in economic activities, as stated by the CJEU in Höfner and consistently held in subsequent case law. ${ }^{26}$ The interpretation of 'undertaking' has been quite broad. However, after the entry into force of the Treaty of Lisbon, the CJEU seems to have (slowly) moved towards a more 'restrictive' approach to the notion of undertaking, allowing public funding to entities that fall short of that notion to protect and promote certain activities having a social value. ${ }^{27}$ In particular, there are two fields in which the scope of application of EU state aid law seems to have been sensibly narrowed: the field of cultural activities and that of education.

With regard to the former, it is worth recalling that benefits that support cultural entities are generally considered to constitute state aid, but they can be allowed under Article 107(3)(d) TFEU, or as it will be discussed later, exempted from notification under the GBER. The 2016 Commission Notice on the notion of aid has further clarified that "public funding of a cultural or heritage conservation activity accessible to the general public free of charge fulfils a purely social and cultural purpose which is non-economic in nature' (emphasis added). The Commission also explained that, even when visitors to a cultural institution or participants in a cultural or heritage conservation activity are required to pay a monetary contribution that only covers a fraction of the true costs, the non-economic nature of that activity is not altered. In this respect, the Notice is quite innovative. ${ }^{28}$ Indeed, up to 2016 , the Commission had systematically taken the view that cultural activities were, in principle, to be considered as economic in nature and capable of falling within the remit of the state aid rules, despite most of the aid measures being considered compatible with the internal market. ${ }^{29}$ It might be argued that the new approach of the Commission and the emphasis on the social role of culture sits well with a 'socially oriented' interpretation of Article 107(1) TFEU in light of Article 3(3) TEU and 9 TFEU. $^{30}$

\section{(F'note continued)}

measures that compensate for the provision of a public service, and which may well be a social service. On this aspect see JJ Piernas López, 'Services of General Economic Interest and Social Considerations' in Ferri and Cortese, note 2 above, p 166.

26 The CJEU has consistently held that any activity consisting of offering goods and services on a market is an economic activity, and that an entity carrying out such an activity is an undertaking for the purpose of application of EU competition law (including state aid rules). See Klaus Höfner and Fritz Elser v Macrotron GmbH, C-41/90, EU:C:1991:161.

27 European Commission, 'Notice on the Notion of State Aid as Referred to in Article 107(1) of the Treaty on the Functioning of the European Union' [2016] OJ C262/1; W Sauter, 'The Notion of Undertaking' in H Hofmann and C Micheau (eds), State Aid Law of the European Union (Oxford University Press, 2017), p 74.

28 P Mengozzi, 'Le attività culturali e la comunicazione della Commissione del 19 luglio 2016 sulla nozione di aiuto di Stato' (2016) Il Diritto dell'Unione Europea 741.

29 D Ferri, 'Cultural Diversity and State Aids to the Cultural Sector' in E Psychogiopoulou (ed), Cultural Governance and the European Union. Protecting and Promoting Cultural Diversity in Europe (Palgrave, 2015), p 119.

30 This also sits well with the relevant role that culture and cultural diversity have in the Treaties. See Article 3(3) TEU, which provides that the EU shall 'respect its rich cultural and linguistic diversity, and shall ensure that Europe's cultural heritage is safeguarded and enhanced', and Article 167 TFEU. 
Another field in which the scope for the application of state aid rules has been limited is that of education. The CJEU has consistently held that public education organised within the national educational system, funded and supervised by the State, may be considered to constitute a non-economic activity. Therefore, it has said, the State, 'by establishing and maintaining such a system of public education [...] does not intend to become involved in activities for remuneration, but carries out its task towards its population in the social, cultural and educational areas' (emphasis added). ${ }^{31}$ The line between economic and non-economic activities in the educational field is not always clear-cut, and can, in reality, be quite porous. However, there is a clear scope for the State to subsidise educational activities without becoming caught within the prohibitions laid down in the Treaty. This is well-exemplified by the decision in Congregación de Escuelas Pías Provincia Betania. ${ }^{32}$ In this case, the Court was again confronted with the scope of application of state aid rules to the educational sector. In particular, the CJEU considered whether a tax exemption granted by Spanish authorities to the Catholic Church, in respect of educational activities, constituted state aid prohibited under Article 107(1) TFEU. The CJEU noted that the Congregación was engaged in three types of activity: strictly religious activities, education subsidised by the Spanish State and integrated within the system of public education, and non-compulsory education receiving no financial support from the State. The tax exemption at issue concerned the renovation and extension of the school hall used for educational activities. The CJEU ultimately left to the national court to decide whether or not the tax exemption fell within the remit of application of Article 107(1) TFEU, as it was a preliminary ruling, and the referring national court found that the tax exemption did in fact constitute state aid in its judgment of 8 January $2018 .{ }^{33}$ However, the CJEU clearly stated that this provision would be applicable only if at least some of the educational activities are classified as 'economic activities' and the hall in question is used, at least in part, for such economic activities, thus beyond religious and public education activities. ${ }^{34}$

As noted by Sauter, the test applied by the Commission and the Court to verify whether an activity is economic is continually being refined and diversified across different sectors. ${ }^{35}$ This refined test also leaves the door open to weigh social considerations, and consequently allows Member States some leeway to support activities that fulfil social rights. The way in which the notion of undertaking has been interpreted and applied in relation to the cultural and educational field are just two examples that show a clear attempt to strike a balance between the 'market' and the

\footnotetext{
31 Commission v Germany, C-318/05, EU:C:2007:495, para 68.

32 Congregación de Escuelas Pías Provincia Betania v Ayuntamiento de Getafe, C-74/16, EU: C:2017:496.

33 Administrative Court of Madrid, Section 4, Case 247/2014.

34 On the case, see A Biondi, 'Congregación de Escuelas Pías Provincia de Betania (Congregación),
} A Tax Exemption for the Catholic Church in Spain Constitutes State Aid if it Concerns Education Services Provided on a Commercial Basis' (2018) 9(2) Journal of European Competition Law \& Practice 110-12.

35 See Sauter, note 27 above, p 83. 
'social'. Albeit indirectly, the endeavour to balance economic considerations linked to the preservation of competition in the internal market and social goals (pursued by the Member States) seems to have been facilitated by the renewed constitutional framework.

\section{B. The 'social dimension' of selectivity}

As noted above in Section II, Article 107(1) TFEU declares 'any aid' a priori incompatible with the internal market. The concept of state aid is objective, ${ }^{36}$ and under well-established case law, Article 107(1) TFEU 'does not distinguish between the measures of State intervention concerned by reference to their causes or aims but defines them in relation to their effects. Consequently, the alleged fiscal nature or social aim of the measure in issue cannot suffice to shield it from the application of Article [107]' (emphasis added). ${ }^{37}$ However, the possibility of taking into account the objectives of a given measure, particularly the social ones, has slowly emerged in the 'selectivity' to exclude the application of Article 107(1) TFEU. This possibility can be traced back to the Maribel bis/ter decision, ${ }^{38}$ which dates back to the late 1990s, long before the entry into force of the Treaty of Lisbon. However, it has become more evident in more recent cases.

In Maribel the Court analysed whether a measure applicable only to some sectors of the Belgian economy could be considered as a general measure (not implying aid) in relation to the fact that the exclusion of some sectors from the application of the measure was due to its alleged social objective (ie promotion of employment of manual workers). In particular, the measure under review consisted of a reduction in social charges to some sectors that were mostly exposed to international competition and benefitted certain sectors of the Belgian economy explicitly listed in the legislation. Two companies referred the case to the Commission: one of them claimed that support for the sectors most exposed to international competition was incompatible with the state aid rules. The other claimed that this support was discriminatory (against Belgian undertakings not benefitting from the aid) and demanded to be afforded equal treatment. The Belgian Government submitted that the Maribel bis/ ter scheme was a general measure. It argued that a measure directed to 'all undertakings', is a measure directed to undertakings which are 'in an objectively similar position'39 and not 'all undertakings' in a given Member State, otherwise it would be very difficult to adopt social, fiscal, or economic policy measures, as they hardly apply simultaneously to all undertakings in a given Member State. In this regard, the Belgian Government noted that the Commission itself had conceded, in a Communication on the monitoring of state aid and reduction of labour costs, that measures favouring certain categories of workers, therefore benefitting only those

\footnotetext{
36 France v Ladbroke Racing and Commission, C-83/98 P, EU:C:2000:248, para 25.

37 Italian Textiles, 173/73, EU:C:1974:71, para 13.

38 Belgium v Commission ('Maribel'), C-75/97, EU:C:1999:311.

39 Ibid, para 17.
} 
undertakings employing those categories of workers, did not constitute state aid if they applied automatically and without discrimination. ${ }^{40}$ In fact, the Commission had already explicitly referred to "companies which are in the same objective position' in a 1996 decision. ${ }^{41}$ The case ended up in front of the CJEU and the Court confirmed (as the Commission did) that the measure was selective because it was restricted to certain sectors of the Belgian economy. ${ }^{42}$

However, the Court did not end the analysis at that point. Instead, the CJEU examined whether the exclusion of some sectors from the application of the measure was compatible with its alleged objective (ie promotion of employment of manual workers), and noted that the objectives of the measure at stake were compatible with the general social system in force in Belgium. The Court also held that Member States retained important powers in the field of social security systems. It also stated that they could, through the redistribution of social charges, pursue, inter alia, the objectives advanced by the Belgian authorities, namely, the maintenance of a high level of employment amongst manual workers and the maintenance of an industrial sector in order to balance the Belgian economy. However, according to the Court, the achievement of those objectives did not justify reducing the scope of application of the measure at stake only to some undertakings (those chosen by the measure). ${ }^{43}$ Interestingly, the Court accepted the interpretation of the concept of 'all undertakings' given by the Belgian authorities. Nevertheless, in the end, it found that some of the sectors excluded from the contested measures (as the tertiary or the building sector) were in a comparable situation to those sectors benefitting from the contested measures, and concluded that the measure was prima facie selective.

Once this prima facie selectivity was established, the Court also examined whether the contested scheme could be justified by the nature or general scheme of the Belgian social security system. ${ }^{44}$ While admitting that the measure could only be

40 European Commission Notice, 'The Monitoring of State Aid and Reduction of Labour Costs', 97/C 1/05 [1997] OJ C1, p 10.

41 In the decision, the Commission argued: 'To differentiate between state aid and general measures the Treaty provides the Commission only with the criterion of specificity, aid being defined in Article 92 of the Treaty as measures "favouring certain undertakings or the production of certain goods". A comparison should therefore be made, within one and the same Member State, between the treatment of companies benefiting from the measure in question and the general system applied to companies which are in the same objective position' (Commission Decision of 13 March 1996 concerning fiscal aid given to German airlines in the form of a depreciation facility, 96/369/EC).

42 Maribel, note 38 above, para 32.

43 The measure excluded some industrial sectors where manual labour was high (therefore sectors in an objectively similar position in the sense of the argument put forward by Belgium) and included other non-industrial such as horticulture and forestry in which manual labour was low. The Commission had shown in its decision that the only $47 \%$ of manual workers were employed in the sectors benefiting from the measure whereas $53 \%$ of them were working in sectors excluded from the measure (Commission decision of 4 December 1996 concerning aid granted by Belgium under the Maribel bis/ter scheme (97/239/EC), [1996] OJ L95/25).

44 In this regard, the Commission emphasised in its pleadings that the 'justification for the measures to reduce the burden of social security costs adopted under the Maribel bis/ter scheme should be sought in the internal logic of the general social welfare system existing in Belgium and not in the specific purpose 
justified by the general social security system applicable in Belgium (and not by the Maribel scheme), the Luxembourg judges took into account the objectives pursued by the general social security system. Furthermore, the Court noted that the objectives of the general social security system were very close to the objectives pursued by the contested scheme, ${ }^{45}$ and that Member States retained the power to organise their social security systems and to promote objectives of employment policy, such as those pursued by both the Maribel bis/ter scheme and the general social security system applicable in Belgium. ${ }^{46}$ Nevertheless, the Court concluded that those objectives could not justify the selective character of the advantage under review. ${ }^{47}$

The CJEU confirmed the Commission's decision and endorsed its approach. It also implicitly supported the selectivity test contained in the notice on direct business taxation and state aids published while this judgment was pending by following the derogation-justification analysis proposed in that notice. However, the victory for the Commission was a pyrrhic one. The Court also introduced some important qualifications to the discrimination-like test for selectivity defended by the Commission since the early 1990s by concluding that the concept of 'all undertakings' referred to those in a comparable position by reference to the objective pursued by the measure, and not to all undertakings in a given Member State, as the Commission had traditionally claimed. Secondly, contrary to the Commission's submissions, the CJEU took into consideration the social objectives pursued by the contested measure at the general systemic level and not, or at least not only, the internal logic of the general social welfare system. Therefore, the Court seems to have struck a balance between the application of the state aid rules, particularly the definition of aid under Article 107(1) TFEU, and the social objectives pursued by the measure under review. The social character of the measure under review, its social aim, seems to have been relevant to the Court in deciding this case, despite the traditional formula, according to which neither the fiscal character nor social aim of a given measure are relevant for the definition of state aid under Article 107(1) TFEU. In sum, as already noted by Armstrong, the social purpose of aid is not irrelevant; still 'the difficulty lies in determining at which level of analysis social aims are to be considered' ${ }^{48}$

More recent cases have also underlined the importance of the objectives of the aid measure under review for the purposes of determining whether a certain undertaking or group of undertakings is in a comparable situation with others. In particular, in

(F'note continued)

of the scheme'. Maribel, note 38 above, para 18. The Commission's position was in fact coherent with the test that it had included in its notice on direct business taxation and state aid, published while this case was pending. European Commission Notice, 'The Application of the State Aid Rules to Measures Relating to Direct Business Taxation' [1999] OJ C384/3.

45 Maribel, note 38 above, para 36.

46 Ibid, para 37.

47 Ibid, paras 38-39.

48 Armstrong, note 24 above, p 204. 
Paint Graphos, ${ }^{49}$ the Court of Justice found that the factual and legal situation of workers and producers' cooperatives in Italy was quite different from that of ordinary capital companies. Therefore, it held that the application of a special regime under the Italian corporate tax code, which provided for the exception of corporate tax for these cooperatives, did not amount to state aid. In particular, the Court underlined that, even if the reference framework for the purposes of the analysis of fiscal selectivity is a wide one, the Commission will have to show that the undertakings exempted from a given tax and those subject to it are in a comparable factual and legal situation in light of the objective pursued by the corporation tax regime. Only if that is the case, prima facie selectivity will be established, yet 'it will still be necessary to determine' whether the tax exemption at stake is justified by the nature or general scheme of the system of which it forms a part. For these purposes, the burden of proof will be on the Member State concerned to show that the measure is justified. ${ }^{50}$ In the same vein, in $A N G E D$, the Court observed that a tax on large commercial establishments the Catalonian Parliament introduced in 2000 ('IGEC') in order to offset the potential impact of those large retail establishments on the territory and the environment was partially selective because it was only applicable to individual retail establishments, the effect of which was to exempt from the IGEC collective large retail establishments with a surface area equal to or greater than $2,500 \mathrm{~m}^{2} .51$ The Court noted that the distinction between individual and collective large retail establishments, two categories of establishment that are objectively in a comparable situation in the light of the objectives of environmental protection pursued by the IGEC, made the exemption of the collective large retail establishments selective. Given that the other conditions under Article 107(1) TFEU were met, this exemption was considered to be state aid. By contrast, the Court found that retail establishments subject to the IGEC and those excluded for having a sales area of less than $2,500 \mathrm{~m}^{2}$ were not in a comparable situation in the light of the objectives pursued by the legislation and concluded that the tax exemption at stake was not selective. $^{52}$

As recently stated by Advocate General Saugmandsgaard Øe, ANGED makes clear that it should be possible to invoke any legitimate objective-including social ones - in the context of the fiscal selectivity test, namely in the examination of comparability. ${ }^{53}$ It is not clear whether this approach can be linked directly to the constitutional innovations introduced by the Treaty of Lisbon. However, it seems that the Court has sought to achieve a better balance between purely market goals and social

\footnotetext{
49 Paint Graphos and Others, C-78/08, EU:C:2011:550, paras 54, 64.

50 JL Buendía Sierra, 'Finding Selectivity or the Art of Comparison' (2018) 17 European State Aid Law Quarterly 85-92.

51 ANGED v Catalonia, C-233/16, EU:C:2018:280.

52 Ibid.

53 Opinion of the Advocate General Saugmandsgaard Øe, Finanzamt B v A-Brauerei, C-374/17, EU: C:2018:741, para 159. See also paras 150 and 151 in which the Advocate General questions the traditional difference between intrinsic and extrinsic objectives for the identification of comparable undertakings under the selectivity analysis in fiscal measures.
} 
considerations, leaving (at least potentially) the door open to a more socially oriented selectivity test.

\section{The 'social dimension' of the market economy operator principle}

For a measure to be considered as state aid under Article 107(1) TFEU, it must confer an advantage on the recipient. Under well-established case law, when public bodies, including public undertakings, carry out economic transactions in line with normal market conditions as a private operator would carry them, no advantage is conferred on the counterpart of the public body or undertaking. This test, usually referred to as the 'market economy operator principle' (MEO principle), has been one of the most litigated areas of EU state aid law. ${ }^{54}$ In this context, the influence of Article 3(3) TEU has been most visible because the European courts have explicitly referred to the notion of 'social market economy' in the application of this test. This notion has served as a backdrop to modulate the strict interpretation of the MEO principle, in order to take into account social considerations. In Corsica Ferries, ${ }^{55}$ the General Court noted that:

in a social market economy, a reasonable private investor would not disregard, first, its responsibility towards all the stakeholders in the company and, second, the development of the social, economic and environmental context in which it continues to develop. The challenges relating to social responsibility and the entrepreneurial context are, in actual fact, capable of having a major impact on the specific decisions and strategic planning of a reasonable private investor. The long-term economic rationale of a reasonable private entrepreneur's conduct cannot therefore be assessed without taking account of such concerns. ${ }^{56}$

The judgment of the General Court in this case was upheld by the Court of Justice, and its core content has also been included in the Commission's Notice on the notion of aid. ${ }^{57}$ The Court has accepted that a seemingly non-market-conformant transaction by a public body does not confer an economic advantage under Article 107(1) TFEU if it can be justified by social considerations that a reasonable private investor in a social market economy would have also observed. So far, this case 'is the only one in which "social market economy" is taken on to directly uphold the Court's reasoning aimed at pinning down the notion of a "reasonable private investor", 58 However, this case opens the door to a more socially oriented interpretation of the MEO principle.

54 P Ibañez Colomo, 'State Aid Litigation before EU Courts (2004-2012): A Statistical Overview' (2013) 4(6) Journal of European Competition Law and Practice 469.

55 Corsica Ferries, T-565/08, EU:T:2012:415. The 'social market economy' was also mentioned by the General Court in another case concerning state aid and environmental protection, namely, Castelnou Energía, T-57/11, EU:T:2014:1021.

56 Ibid, para 82.

57 European Commission 'Notice on the Notion of State Aid as Referred to in Article 107(1) of the Treaty on the Functioning of the European Union' [2016] OJ C262/1.

58 S Civitarese Matteucci, 'Social Rights, Social Market Economy and the European Social Model. Tracing Conceptual Boundaries' in Ferri and Cortese, note 2 above, p 59. 


\section{The 'social dimension' of the effect on trade criterion}

The relevance of social considerations has emerged sharply in the interpretation of the 'effect on trade'. Until after the entry into force of the Treaty of Lisbon, on several occasions, the Commission had considered to be state aid even those measures whose effects on intra-EU trade were only potential or negligible. Most of them concerned the social measures of schemes aimed at supporting cultural initiatives. ${ }^{59}$ In recent years, by contrast, the Commission has recognised that certain measures had a purely local impact, were unlikely to attract customers or investment from other Member States, and therefore had no effect on trade between Member States, excluding them from the scope of application of Article 107(1) TFEU. Most of those had a social character. They concerned sports and leisure facilities serving predominantly a local audience, cultural events, social support services to the elderly and people with disabilities, or hospitals and other health care facilities providing the usual range of medical services aimed at a local population. ${ }^{60}$ These decisions were backed by various Commission statements, highlighting that aid measures directed at specific social projects at the local level do not necessarily result in state aid according to EU law. ${ }^{61}$

These Commission decisions ought to be taken with caution, given that the case law of the Court has consistently held that the relatively small amount of aid or of the size of the undertaking which receives it does not, as such, exclude the possibility that trade between Member States might be affected. ${ }^{62}$ However, they show the Commission's willingness to exclude from the notion of aid, and therefore from the ex ante notification system, public support measures to social initiatives adopted locally within the Member States. In recognizing that those initiatives were unlikely to affect intra-EU trade (as is indeed the case), the Commission has significantly narrowed down the scope of application of EU state aid rules.

\section{BALANCING THE 'MARKET' AND THE 'SOCIAL' IN THE COMPATIBILITY ASSESSMENT OF STATE AID}

European social goals, such as those of combating poverty and social exclusion, embedded in Article 3 TEU, propounded in several soft law documents, and most recently proclaimed in the European Pillar of Social Rights ('EPSR'), are becoming more and more relevant in the analysis of the compatibility of state aid under the

\footnotetext{
59 A notable example in this respect is the Dutch scheme for conservation and restoration of protected historical monuments. State Aid - N 606/2009 - The Netherlands 'National framework for conservation and restoration of protected historical monuments'. See also State Aid N-SA. 33433- Czech Republic 'Green Knowledge Centre/ Open-air museum, Town of Bystřice nad Pernštejnem'.

60 European Commission 'Notice on the Notion of State Aid as Referred to in Article 107(1) of the Treaty on the Functioning of the European Union' [2016] OJ C262/1, pp 196-97, and the Commission's press releases of 29 April 2015 (IP/15/4889) and 21 September 2016 (IP/16/3141).

61 See in this regard the Commission's press release of 12 May 2017, at https://ec.europa.eu/futurium/ en/content/no-cross-border-effect-aid-measure-no-state-aid.

62 Eventech v The Parking Adjudicator, C-518/13, EU:C:2015:9, para 65.
} 
Treaty. ${ }^{63}$ The subsections below attempt to show that, in relation to the de jure derogations provided in Article 107(2) TFEU, to the discretionary derogations under Article 107(3) TFEU, and to the secondary legislation adopted pursuant to this provision, particularly the GBER, the Commission has developed its own vision of 'good' state aid policy. In particular, in the post-Lisbon era, the Commission has identified specific European social objectives which are of relevance in order to declare public support measures compatible with the internal market.

\section{A. De jure derogations}

Article 107(2) TFEU specifies a number of cases in which national measures are permissible. The Commission has no discretion as to whether to authorise the aid when the criteria set forth in that provision are met. ${ }^{64}$ This section focuses on one of those criteria, namely, social aid under Article 107(2)(a) TFEU. ${ }^{65}$ The latter provision exempts measures having 'a social character' granted to individual consumers, without discrimination in terms of the origin of the products. This derogation allows and justifies a State intervention to protect certain disadvantaged segments of the population and certain social rights.

In the past, the Commission had consistently argued that the term 'social character' should be interpreted narrowly and refer to aid 'addressing the needs of underprivileged population groups' ${ }^{66}$ This strict interpretation was in line with the general principle that ' $\ldots$ the exceptions to the general rule of incompatibility of the aid with the [internal] market must be interpreted narrowly' ${ }^{67}$ Indeed, aid of a social character was interpreted as aid solely and directly for the disadvantaged sections of the population, and had primarily been applied in the air transport sector. In several decisions, the Commission argued that reduced airline fares must only benefit certain disadvantaged groups, such as the elderly, disabled, or some other specific class (whilst the aid must not benefit a specific airline in a discriminatory manner) ${ }^{68}$ Still, a more flexible interpretation was carved out by the Commission when

${ }^{63}$ European Commission, 'Statement of President Juncker on the Proclamation of the European Pillar of Social Rights' (2017), at http://europa.eu/rapid/press-release_STATEMENT-17-4706_en.htm. S Garben, 'The European Pillar of Social Rights: An Assessment of its Meaning and Significance' (2019) 21 Cambridge Yearbook of European Legal Studies.

${ }^{64}$ MF Orzan, 'De Jure Compatible Aid under Article 107(2) TFEU' in Hofmann and Micheau, note 27 above, p 234.

65 Article 107(2)(b) TFEU lists aid that 'makes good the damage caused by natural disasters or exceptional occurrences'. This provision also mentions at letter (c): 'aid granted to the economy of certain areas of the Federal Republic of Germany affected by the division of Germany, in so far as such aid is required in order to compensate for the economic disadvantages caused by that division'. This exemption is of limited practical relevance, and is now ex lege repealed.

${ }^{66}$ State Aid decision C 52/05, Subsidy to digital decoders, [2007] OJ L147/1. See also the subsequent CJEU decisions: Mediaset v Commission, T-177/07, EU:T:2010:233; Mediaset SpA v Commission, C-403/10 P, EU:C:2011:533.

67 Ibid.

68 J Faull and A Nickpay, The EU Law of Competition (Oxford University Press, 2014), p 1966. 
admitting aid to certain categories of consumers living in remote areas or disadvantaged regions or islands and in need of such aid. ${ }^{69}$ The Commission argued that the eligible categories of disadvantaged groups do not constitute a numerus clausus. It affirmed that 'the aid must have a social character, that is, it must, in principle, only cover certain categories of passengers travelling on a route such as children, handicapped people, people with low income, etc. However, in the case where the route concerned an underprivileged region, the aid could cover the entire population of this region'. ${ }^{70}$ Article 107(2)(a) is now the basis for the exemption laid down in Article 51 of the GBER, which covers aid for air and maritime transport for the benefit of consumers resident in remote regions.

Interestingly, after the entry into force of the Treaty of Lisbon, the way in which 'social character' has been interpreted creates an even greater flexibility over the notion of 'aid having a social character' in a context-driven fashion, related to the recent economic crisis. For example, aside from approving various measures to switch to digital television targeting certain specific disadvantaged groups, ${ }^{71}$ in order to improve social inclusion, the Commission allowed measures that go in the direction of protecting the social rights of the population beyond traditionally disadvantaged groups. This is the case of the 'UK Homeowners Mortgage Support Scheme' or the 'Cyprus State Grant Scheme to Borrowers and Micro-companies, ${ }^{72}$ which were considered compatible with the internal market under Article 107(2)(a) TFEU. These schemes were meant to enable households experiencing a significant and temporary loss of income (because of the economic crisis), to defer principal repayments. They were explicitly designed to help borrowers avoid repossession. The Commission recognised that, although these individuals may not be, as such, part of a disadvantaged group, the worsening economic crisis made them vulnerable, acknowledging the tensions between property rights, market values, and social needs.

Since its inception, Article 107(2)(a) TFEU has allowed subsidies combating different forms of social exclusion and targeting traditionally disadvantaged groups. However, in most recent years, a slightly broader interpretation of 'social character' has allowed Member States to address new forms of poverty, and to tackle, through state aid measures, social justice issues that have a European dimension and the

69 A block exemption of aid for residents of remote regions was introduced through Commission Regulation (EU) 651/2014, Art 51. See also: Commission Decision, Case SA-33966, Aide à caractère social au bénéfice des résidents des îles de la Guadeloupe, 3/5/EU [2012] OJ C128/2; Commission Decision, Case SA-32888, Befreiung von der Luftverkehrsteuer hinsichtlich Abflügen von Inselbewohnern und in anderen Fällen, 8/3/EU [2001] OJ C70/3.

70 State Aid 27/2008 - United Kingdom. Aid of a social character Air Services in the Highlands and the Islands of Scotland, dated 14 November 2008 C(2008)685.

71 In 2010, the Commission approved an aid measure for the purchase of set of digital boxes for socially vulnerable people in Slovakia (SA.32566). In 2012, the Commission approved aid measures for the purchase of digital decoders by socially disadvantaged households in Hungary (SA.34901). In 2011, a similar measure aimed at the distribution of digital decoders to persons with visual disabilities in Spain was approved (SA.31982).

72 SA.45004 (2016/N) - Cyprus State Grant Scheme to Borrowers and Micro-companies. 
Commission itself had already somewhat broadly identified in other policy measures. In this regard, the approval of aid measures to support householders and protect them from repossession should not be viewed as a temporary response to the harsh economic crisis. Rather, it must be seen within the broader context of EU policy measures to combat poverty and enhance social cohesion across Europe. Since 2010, which was the European Year for Combating Poverty and Social Exclusion, and in line with 'Europe 2020, ${ }^{73}$ the Commission has launched various initiatives to promote inclusive growth, and tackle homelessness, housing exclusion, financial exclusion, and high indebtedness. ${ }^{74}$ The European Pillar, solemnly proclaimed on November 2017, also goes in this direction. Principle 19 of the EPSR affirms that "vulnerable people have the right to appropriate assistance and protection against forced eviction', while stating that social housing and related services must be ensured. While it is not entirely clear what the effects of the EPSR will be, it may support broader interpretation of 'social character'. Overall, the Commission's approach in applying Article 107(2)(a) TFEU seems underpinned by the EU overall objectives laid down in Article 3 TEU.

\section{B. Discretionary derogations}

As discussed above, Article 107(3) TFEU stipulates that some forms of aid may be considered compatible with the internal market. Among them, it lists aid to promote the economic development of areas where the standard of living is abnormally low or where there is underemployment (lett. a), aid to promote the execution of a project of common European interest or to remedy a serious disturbance in the economy of a Member State (lett. b), aid to facilitate the development of certain economic activities or of certain economic areas, where such aid does not adversely affect trading conditions to an extent contrary to the common interest (lett. c), and aid to promote culture and heritage conservation (lett. d). While well-established case law has consistently held that Article 107(3) must be interpreted strictly, ${ }^{75}$ the Commission, when comparing and balancing the positive effects of the aid against its distortion of competition, enjoys a significant discretion in carrying out an assessment of economic, technical, and policy considerations, and moulding Member States' policies aimed at protecting and promoting social rights. Without examining the technicalities pertaining to each of these categories of aid, this subsection focuses on Article 107(3)(a), (b), and (c). It endeavours to highlight that, since the entry into force of the Treaty of Lisbon, to varying degrees, the assessment performed by the Commission is informed by social objectives of common interest, mentioned in Article 3 TEU, pursued in the context of broader EU social policies and in the Europe 2020 strategy, and revamped in the EPSR.

73 COM (2010) 2020 final, A European Strategy for Smart, Sustainable and Inclusive Growth.

74 COM (2010) 758 final, The European Platform against Poverty and Social Exclusion: A European Framework for Social and Territorial Cohesion.

75 Among many others, Philip Morris, C-730/79, EU:C:1980:209. 


\section{Regional aid}

The horizontal category of 'regional aid' provided for in Article 107(3)(a) and (c) TFEU aims to support economic development and job creation in Europe's most disadvantaged regions. ${ }^{76}$ It has, first and foremost, a geographical dimension, as it applies only to those areas that experience an economic or social disadvantage. Article 107(3)(a) TFEU concerns areas where the economic situation is unfavourable in relation to the Union as a whole, ${ }^{77}$ while Article 107(3)(c) allows more flexibility in terms of identifying the areas in which the Member State can use the aid. The latter derogation has a wider scope, as it allows for aid to areas that do not satisfy the conditions set out by lett. a. The Commission has the power to authorise aid intended to further the economic development of areas of a Member State that are disadvantaged in relation to the national situation.

Although most of the regional aid is now block exempted, the economic approach endorsed by the General Court in Hotel Cipriani (long before the entry into force of the Treaty of Lisbon) appears to still be the rule when it comes to the assessment of regional aid. This implies that the Commission must carefully evaluate the anticompetitive effects of the aid. In Hotel Cipriani, the General Court rejected a teleological interpretation of Article 107(3)(c) TFEU which favoured the goal of social cohesion. The applicant, Hotel Cipriani, had argued that the provision should have been interpreted in accordance with the objectives of economic and social cohesion laid down in the Treaty. It also put forward the view that 'the realisation of [an internal] market and the protection of competition do not constitute an end in themselves but are intended to realise the essential objectives of the Treaty', and that regional aid constituted 'an essential instrument in the pursuit of those objectives'. The General Court rejected this thesis and affirmed that 'regional state aid promotes the economic, social and territorial cohesion of Member States and the [EU] as a whole cannot therefore have any bearing on the interpretation of the rules governing regional state aid'. It went on to affirm that 'the Commission is not required, in the exercise of its discretion, to apply those rules in a more flexible way so as to favour the objectives of the policy of economic and social cohesion over those of competition policy'. In a similar vein, the 'Guidelines on Regional State Aid for 2014-2020' specify that the Commission in its assessment must analyse "whether the design of the aid measure ensures that the positive impact of the aid towards an objective of common interest exceeds its potential negative effects on trade and competition'. ${ }^{78}$

The Commission has consistently performed a rigorous economic analysis, and there has not been any definite cleavage in the cautious approach it adopted in the

\footnotetext{
76 Regional aid concerns all sectors of economic activity, apart from the fisheries and aquaculture, agricultural, and the transport sector, which are subject to special rules (European Commission, 'Guidelines on Regional State Aid for 2014-2020', [2013] OJ C209/1, paras 10, 30).

77 Germany v Commission, C-248/84, EU:C:1987:437. In particular, the CJEU has consistently held that the use of the words 'abnormally' and 'serious' in Article (107)(3)(a) shows that the exemption concerns only areas where the economic situation is extremely unfavourable in relation to the EU as a whole.

78 See note 76 above.
} 
post-Lisbon framework. However, in the assessment of regional aid the 'social dimension' of the aid measure and its value in terms of balanced and sustainable European growth plays an undoubtedly important role. This emerges quite strikingly in the 'Guidelines on Regional State Aid for 2014-2020', ${ }^{79}$ which define the regions eligible for aid and the criteria governing the assessment of regional aid. These guidelines clearly state that 'through its equity or cohesion objective regional aid may contribute to the achievement of the Europe 2020 strategy delivering an inclusive and sustainable growth' ${ }^{80}$ The reference to these EU social goals cannot be considered merely rhetorical or ancillary. The guidelines in fact suggest a variety of indicators to identify the positive effects of the aid and its contribution to regional development, which, for the most part, have a social nature, such as the number of direct and indirect jobs created by the investment. These indicators allow the Commission to authorise those regional aids that have demonstrably European social benefits. These indicators are now mirrored in the three dimensions of the 'social scoreboard' that monitors the implementation of the EPSR in EU countries, ${ }^{81}$ in particular that of 'equal opportunities and access to the labour market'. This dimension covers, inter alia, aspects of fairness related to education, skills, and lifelong learning, which are crucial to demonstrate the regional contribution of the aid notified to the Commission. Furthermore, the indicators are related to the overall objectives of the EU2020 strategy, and more broadly to the goals laid down in Article 3 TEU. On the whole, the regional aid measures, which 'attempt to buffer political and social tension between or within Member States by equalising wages and income, increasing employment in lagging regions or reducing migration incentives', pay tribute to the 'social' in the 'social market economy' envisaged in Article 3 TEU. ${ }^{82}$

\section{Aid to remedy a serious disturbance in the economy and the financial crisis: a hidden 'social dimension'?}

During the financial crisis that hit Europe after the dramatic fall of Lehman Brothers in the summer of 2008, ${ }^{83}$ Article 107(3)(b) TFEU was used to allow Member States to subsidise financial institutions, mainly through capital injection, in an attempt to stop the turmoil of the financial markets and to avoid their collapse. ${ }^{84}$

Before the crisis, the scope of application of Article 107(3)(b) TFEU was extremely narrow. The CJEU had clarified that 'aid cannot be benefiting only one

79 Ibid.

80 Ibid.

81 See European Commission, 'Social Scoreboard', https://composite-indicators.jrc.ec.europa.eu/ social-scoreboard/\# socialdimensions.

82 H Friederiszick and M Merola, Regional State Aid Control in Europe: A Legal and Economic Assessment (European School of Management and Technology, 2015) Working Paper No 15-05.

83 J Breslin, Banking Law (Thomson Round Hall, 2013), p 8.

84 C Koenig, "Instant State Aid Law" in a Financial Crisis, State of Emergency or Turmoil: Five Essential and Reasonable Requirements under the Rule of Law' (2008) European State Aid Law Quarterly 629. 
company or one sector but must tackle a disturbance in the entire economy of a Member State', ${ }^{85}$ and consistently held that aid measures approved under Article 107(3)(b) cannot 'resolve the problems of a single recipient [...], as opposed to the acute problems facing all operators in the industry'. ${ }^{86}$ However, when the Commission adopted the first Banking Communication in $2008,{ }^{87}$ and then a series of other soft law documents to set forth criteria to assess aid to financial institutions and coordinate Member States reaction to the crisis, ${ }^{88}$ this Treaty provision was deemed the most appropriate derogation to allow Member States' action to curb the effects of the crash. The emergency state aid policy ushered in during the financial crisis responded to the necessity to protect the integrity of the internal market. It was limited in a temporal sense, as well as being targeted towards ensuring financial stability in Europe. However, an overall and broad social aim can be identified: that of supporting the real economy, and with that the labour market and, even more obviously, the access to finance. In the 2009 Communication on the 'Temporary Framework for State Aid Measures to Support Access to Finance in the Current Financial and Economic Crisis', ${ }^{89}$ which expired in 2011, the Commission made it clear that:

[w] hile the situation on financial markets appears to be improving, the full impact of the financial crisis on the real economy is now being felt. A very serious downturn is affecting the wider economy and hitting households, businesses and jobs (emphasis added).

The flexible and proactive approach to the use of state aid during the financial crisis adopted by the European Commission, though criticised in many respects, ${ }^{90}$ eventually succeeded in containing the global threat to economic and social stability. It avoided a suspension of the state aid discipline, as it was suggested by some Member States..$^{91}$ Between 2008 and 2011, the Commission took over two hundred

85 Freistaat Sachsen and Volkswagen AG Commission, Joined Cases T-132/96 and T-143/96, EU: $\mathrm{T}: 1999: 326$, para 167.

86 Crédit Lyonnais, C-47/1996, [1998] OJ L221/28, para 10.1.

87 Communication from the European Commission, 'The Application of State Aid Rules to Measures Taken in Relation to Financial Institutions in the Context of the Current Global Financial Crisis', [2008] OJ C270/8. A new Banking Communications was issued in 2013 to replace the existing 2008 Communication (Communication from the European Commission, 'Application of State Aid Rules to Support Measures in Favour of Banks in the Context of the Financial Crisis', [2013] OJ C216/1).

88 A Bomhoff, A Jarosz-Friis, and N Pesaresi, 'Restructuring Banks in Crisis-Overview of Applicable State Aid Rules' (2009) Competition Policy Newsletter 3.

89 Communication from the European Commission, 'Temporary Framework for State Aid Measures to Support Access to Finance in the Current Financial and Economic Crisis', [2011] OJ C6/5.

90 H Gilliams, 'Stress Testing the Regulator: Review of the State Aid to Financial Institutions after the Collapse of Lehman’ (2011) European Law Review 3.

91 See, in this regard, the speech by H Ungerer, Deputy Director General of DG Competition with Special Responsibility for State Aids, at the EU State Aid Summit State Aid Policy, Procedure and Enforcement through the Economic Crisis and Beyond C5 Business Information in a Global Context, Brussels, p 13. It is available at: http://ec.europa.eu/competition/speeches/text/ sp2009_11_en.pdf. He referred to Article 107(3)(b) as a 'nuclear option' of state aid law. See also in 
decisions authorising aid measures to the financial sector. ${ }^{92}$ The improved market conditions since 2013 have signalled a return to a more restrictive approach to aid to financial institutions. For this reason, the Commission's measures between 2008 and 2011 could be seen as a pragmatic and contextual response to crisis. However, they also seem to point, albeit indirectly, to the fact that the Commission has used state aid control to reduce the very high social costs of an economic and financial crisis, and has the potential to do so again, should similar circumstances arise. Finally, in an interesting case related to a preliminary ruling concerning the interpretation of a Commission decision adopted under Article 107 (3)(b) TFEU, the Court of Justice admittedly showed some flexibility by declaring that Articles 107 TFEU and 108 TFEU, do not preclude the application, in proceedings relating to a collective redundancy, of national legislation under which the compensation payable to an employee whose dismissal is held to be unfair is set at an amount higher than the legal minimum. Consequently, the Court recognised a certain leeway to the national authorities implementing the Commission decision in this social-related case. $^{93}$

\section{Aid to facilitate the development of certain economic activities and social considerations}

Under Article 107(3)(c) TFEU, the Commission has consistently allowed measures indirectly related to the protection and promotion of social rights and aimed at social inclusion of vulnerable groups. ${ }^{94}$ However, from approximately 2009, a series of soft law documents, which clarify the way in which the Commission carries out its assessment, have identified specific social goals that can be pursued by Member States and that match objectives of European interest identified and pursued in other areas of EU policy. For example, in 2009, the Commission set out the criteria to assess the compatibility of notified aid measures for disadvantaged and disabled workers (ie of individual aid targeted to combat unemployment of persons with disabilities, granted either ad hoc or as a part of a scheme where the grant exceeds 10

\section{(F'note continued)}

this regard the Business and Advisory Committee (BIAC) to the OECD: 'An aggressive enforcement of subsidies bans would also have put into danger the very existence of State aid rules, given the strong political and economic reasons for granting aid'. Global Forum on Competition, Roundtable on competition, state aids and subsidies (DAF/COMP/GF(2010)5), p 228.

92 R Ianus and M Orzan, 'Aid Subject to Discretionary Assessment under Article 107(3) TFEU' in Hofmann and Micheau, note 27 above, 240, p 275.

93 See Iglesias Gutiérrez, C- 352/14, EU:C:2015:691.

94 An example can be found in the approval of the Polish state aid scheme N 519/2007 for operators employing persons held in detention, and of its renewed version in 2017. This aid scheme was aimed at providing aid to undertakings employing persons in detention to prepare them for work in the open labour market, after their release from prison. The Commission, in its assessment, found that 'the positive effects of the scheme, namely the promotion of inclusion of vulnerable and marginalised group' outweighed its negative effects. State Aid No SA.46134(2016/N) - Poland State Aid Scheme for Operators Employing Persons Held in Detention (amendment to the aid scheme SA.33608 (2011/N)). 
million euros). ${ }^{95}$ This Communication, as noted elsewhere, while retaining an economic approach shows 'a renewed commitment by the Commission to the promotion of equality and full employment through EU state aid policy', 96 and complements EU goals included in the 'European Disability Strategy 2010-2020' 97

Another notable example is the 2014 Communication on State Aid for Rescuing and Restructuring Non-financial Undertakings in Difficulty, ${ }^{98}$ which builds upon the previous guidelines, ${ }^{99}$ but also takes into account the 'Europe 2020' goals, including that of inclusive growth. The Commission acknowledges that 'rescue and restructuring aid are among the most distortive types of state aid'. For this reason, this type of aid is seen as an extrema ratio; the conditions laid down in the guidelines are aimed to limit as far as possible the anticompetitive effects of the aid. Interestingly, for the purposes of this analysis, the guidelines include a specific section on aid to cover the social costs of restructuring (ie social security payments and other benefits to redundant employees). Member States are generally allowed to provide for general social security schemes for redundant employees as these schemes fall outside the scope of Article 107(1) TFEU. However, since restructuring entails reductions in the workforce or abandonment of certain production activities, Member States are allowed to support restructuring in particular industries in relation to benefits to redundant workers, such as redundancy payments or measures to increase their employability. The guidelines also endorse the adoption of a 'restructuring scheme for training, counselling and practical help with finding alternative employment, assistance with relocation, and professional training and assistance for employees wishing to start new businesses'. The guidelines explicitly state that:

[g]iven that such measures, which increase the employability of redundant workers, further the objective of reducing social hardship, the Commission consistently takes a favourable view of such aid when it is granted to undertakings in difficulty.

In the last couple of years, the Commission assessed a few schemes under the guidelines, such as the Spanish (Basque) 'Restructuring Aid Scheme for SMEs

\footnotetext{
95 Communication from the European Commission, 'Criteria for the Compatibility Analysis of State Aid to Disadvantaged and Disabled Workers Subject to Individual Notification', [2009] OJ C188/6.

96 D Ferri and M Marquis, 'Inroads to Social Inclusion in Europe's Social Market Economy: The Case of State Aid Supporting Employment of Workers with Disabilities' (2011) European Journal of Legal Studies 4.

97 SEC (2010) 1324 final, 'European Disability Strategy 2010-2020: A Renewed Commitment to a Barrier-Free Europe'.

98 Communication from the European Commission, 'Guidelines on State Aid for Rescuing and Restructuring Non-financial Undertakings in Difficulty', [2014] OJ C249/1.

99 After the first guidelines adopted in 1994 and their revised version passed in 1999, the Commission adopted new guidelines in 2004 (European Commission, 'Community Guidelines on State Aid for Rescuing and Restructuring Firms in Difficulty', [2004] OJ C244/2), the validity of which was extended until their replacement by new 2014 rules.
} 
"BIDERATU Berria", ${ }^{100}$ and in all these cases, while approving the aid, carefully assessed whether the aid would effectively mitigate the social and economic consequences that would otherwise occur.

On the whole, these guidelines are illustrative of social objectives being engrained and embedded in the assessment conducted under Article 107(3)(c) TFEU. They show an explicit attempt to mainstream social policy objectives that have a European dimension into state aid control. In this regard, a trend similar to that observed in previous sub-sections can be identified. Although the Commission sticks to an economic approach to state aid, the assessment increasingly takes into account specific social objectives, broadly identified in Article 3 TEU and pursued at the European level in the context of other policy frameworks (such as EU disability policy), and in line with the Europe 2020 strategy.

\section{Aid granted under the General Block Exemption Regulation}

In line with the social policy goals set forth in the Europe 2020 strategy, and arguably with the overall aims set forth in Article 3 TEU, aid exempted from notification has, in most cases, an underlying social dimension. The GBER, ${ }^{101}$ adopted within the framework of the SAM package, ${ }^{102}$ and following the amendment of the Council Enabling Regulation, ${ }^{103}$ which allowed the Commission to declare additional categories of aid compatible with the internal market and therefore exempted from ex ante notification, embodies specific European social objectives to be pursued by Member States. ${ }^{104}$

Among the 43 categories of exemptions, the GBER includes (as its predecessor) training aid and aid for disadvantaged workers and for workers with disabilities. ${ }^{105}$

\footnotetext{
100 C(2017) 4984 final, State Aid SA.47595 (2017/N) - Spain Restructuring Aid Scheme for SMEs 'BIDERATU Berria'.

101 See note 11 above.

$102 \operatorname{COM}(2012) 0209$ final, 'EU State Aid Modernisation (SAM)'. For a discussion of the SAM, see C Quigley, 'The European Commission's Programme for State Aid Modernization' (2013) Maastricht Journal of European and Comparative Law 35.

103 Council Regulation (EC) 994/98 of 7 May 1998 on the application of Articles 92 and 93 EC [now Articles 107 and 108 TFEU respectively] to certain categories of horizontal state aid [1998] OJ L142/1. Repealed by Council Regulation (EU) 2015/1588 of 13 July 2015 on the application of Articles 107 and 108 of the Treaty on the Functioning of the European Union to certain categories of horizontal state aid, OJ L248, 24.9.2015, pp 1-8.

104 As its predecessor (Commission Regulation (EC) 800/2008 of 6 August 2008 declaring certain categories of aid compatible with the common market in application of Articles 87 and 88 of the Treaty General Block Exemption Regulation [2008] OJ L214/3 (amended by Commission Regulation (EU) 1224/2013 of 29 November 2013 amending Regulation (EC) 800/2008 as regards its period of application [2013] OJ L320/2), the GBER sets out the categories of aid and the conditions under which aid measures can benefit of an exemption from notification, define the eligible beneficiaries, the maximum proportion of the eligible costs that can benefit from state aid and eligible expenses. However, the new GBER significantly extends the possibilities for Member States to grant aid.

105 D Ferri, 'The New General Block Exemption Regulation and the Rights of Persons with Disabilities: Smoke without Fire?' (2015) 14 European State Aid Law Quarterly 465.
} 
The preamble explicitly affirms that 'the promotion of training and the recruitment/ employment of disadvantaged workers and of workers with disabilities constitutes a central objective of the economic and social policies of the Union and its Member States' (emphasis added), and several measures have already been adopted by Member States on the basis of this provision. ${ }^{106}$ The GBER also exempts from notification regional aid, social aid for transport for residents of remote regions, aid for culture and heritage conservation, and aid for sport and multifunctional recreational infrastructures. The latter three categories are a novelty and have been introduced by the revised GBER. For all these categories, the GBER emphasises the social dimension justifying the rationale behind the aid. With regards to investment aid for sport infrastructures, for example, the GBER mentions Article 165 TFEU and highlights that 'the Treaty recognises the importance of promoting European sporting issues, while taking account of the specific nature of sport, its structures based on voluntary activity and its social and educational function' (emphasis added) ${ }^{107}$ Even for aid that is not explicitly connected to a social objective, an underpinning social dimension is identifiable. For example, when it comes to aid for small and medium-sized enterprises (SMEs), the GBER acknowledges that 'SMEs play a decisive role in job creation and, more generally, act as a factor of social stability and economic development' (emphasis added). ${ }^{108}$ In a similar vein, when it comes to aid for research and development and innovation, the GBER emphasises that 'it can contribute to sustainable economic growth, strengthen competitiveness and boost employment' (emphasis added). ${ }^{109}$ In that, the GBER echoes the wording of Article 3(3) TEU. State aid in the context of energy, is also underpinned by an explicit European social dimension. When it comes to environmental aid, the GBER refers explicitly to the Europe 2020 strategy. In relation to aid to support energy infrastructures, it also highlights that 'infrastructure construction and upgrade in assisted regions contribute to the economic, social and territorial cohesion of Member States and the Union as a whole by supporting investment and job creation and the functioning of energy markets in the most disadvantaged areas' (emphasis added). ${ }^{110}$ Aid for broadband infrastructure is linked to the importance that connectivity of this nature has 'for a smart, sustainable and inclusive growth and innovation and for social and territorial cohesion'. ${ }^{111}$ In this field, the GBER is intended to support and nudge Members States

\footnotetext{
106 Among many others, SA.40525 Polish Scheme on Wage Subsidies for Workers with Disabilities (2015); SA.40612 Belgian Scheme 'Professionele integratie Personen met een handicap' (2015); SA.39104 Skills Development Scotland Support for Training, the Employment of Disadvantaged/ Disabled Workers and Consultancy 2014-2020 (2014).

107 Commission Regulation (EU) 651/2014, Preamble Rec 74.

108 Ibid, Preamble Rec 40.

109 Ibid, Preamble Rec 45.

110 Ibid, Preamble Rec 67. More generally, State aid rules 'play a key role in meeting the EU's ambitious energy and climate targets', as highlighted by $\operatorname{COM(2018)~} 482$ final, Report on Competition Policy 2017, p 13.

111 Commission Regulation (EU) 651/2014, Preamble Rec 71.
} 
towards connectivity strategic objectives for $2025 .^{112}$ The language used by the GBER clearly highlights a European social dimension and is clearly informed to that of Article 3 TEU.

The GBER operates on the basis of notification thresholds, ie aid can only be awarded under the GBER up to the threshold amount. However, these thresholds have been raised considerably compared to the previous 2008 GBER. In addition, in relation to aid that have an 'equity' objective (or, more broadly, a social dimension) — such as regional operating aid, aid for the recruitment of disadvantaged workers, aid for employment of workers with disabilities and aid compensating for the additional costs of employing workers with disabilities, and social aid for transport for residents of remote regions and aid for culture and heritage conservation-the requirement of the existence of an incentive effect does not apply, ${ }^{113}$ or is presumed as having been complied with.

The enlarged scope and higher amount of aid exempted from notification are counterbalanced by transparency requirements ${ }^{114}$ and by more stringent monitoring and reporting provisions. ${ }^{115}$ This signals that the overall central objective of the Commission's state aid policy remains to encourage Member States to reduce their overall aid levels. Nevertheless, the GBER not only confirms the willingness of the Commission to allow Member States funding aimed at pursuing social goals, but also its increasing efforts to taken into account 'EU social goals' in the application of the state aid rules.

\section{CONCLUSIONS}

Further to the entry into force of the Treaty of Lisbon, social considerations have played a growing, yet limited, role in the application of the state aid rules. Market goals have become more and more intertwined with social objectives.

On the one hand, Member States can now more easily than before pursue their own social goals without triggering Article 107(1) TFEU. In this respect, while internal market legislation has generally expanded its scope of application to erode the Member States' regulatory powers in social policy areas, the scope of application of EU state aid law has been slightly reduced to allow Member States to attain social and redistributive goals. Indeed, Member States have the possibility to advance their own welfare policies to a greater extent than in the pre-Lisbon constitutional framework, due to the way in which the notion of aid has been interpreted in recent years. A clear shift is perceivable in the post-Lisbon context especially in relation to the

\footnotetext{
$112 \operatorname{COM}(2018) 482$ final, Report on Competition Policy 2017, p 9. The Report also highlights that, in 2017, the Directorate-General for Competition of the Commission actively contributed with its expertise on competition law, in particular State aid rules, to the new European Network of Broadband Competence Offices and the Toolkit for Rural Broadband. This also makes evident the European interest in the development of the broadband and the European dimension that state aid in this field has.

113 Article 6(5) GBER.

114 Article 9 GBER.

115 Article 10 et seq GBER.
} 
concept of 'effect of trade'. However, with the exception of the concept of advantage, where the goal of a 'social market economy' has come directly into play in the definition of the market investor principle, the renewed constitutional framework remains rather in the background.

On the other hand, as suggested by Blauberger, the Commission is acting as a 'supranational entrepreneur' by developing, in the context of the compatibility analysis, its own vision of 'bad' aid or of 'good' state aid policy. In this regard, more visibly than before, Member States are incentivised to use national resources to pursue social objectives which are of 'European interest', in view of the targets set forth in the Europe 2020 strategy, but also in line with the objectives set out in other policy documents, such as for example, the European Disability Strategy 2010-2020. The analysis of Commission decisions and of some of the guidelines that inform the Commission's assessment under Article 107(3)(c) show that the Commission has strenuously streamlined national economic policies towards common social objectives, that have a European dimension. Plural references to other policy documents that encapsulate social goals can be found in Commission's decisions and soft law. Moreover, the wording used in the Commission's guidelines and in the GBER explicitly mirrors that of those policy documents, referring to 'inclusive growth', 'social cohesion', and 'sustainable development'. Although there is no trace in the Commission's documents of explicit references to the 'social clauses' included in the Treaty, nor to the 'social market economy', those seem somewhat underpinned in the Commission's reasoning. The economic analysis conducted by the Commission is often informed, as for example in the case of regional aid, by indicators aimed at showing demonstrable social benefits for the EU as whole. On the whole, the Commission has de facto attempted to align national state aid policies with EU social goals through the channelling of national funds to those goals. ${ }^{116}$

Even though the ideal of a 'Social Europe', evoked by Delors in the $1980 \mathrm{~s},{ }^{117}$ is still faraway, the twofold 'social dimension' of EU state aid law and policy discussed in this article shows the attempt of the Commission and of European courts to seek a better balance between internal market goals and social objectives. The social dimension of EU state aid law and policy is certainly 'fluid' and does not have a definite characterization. However, the analysis conducted throughout this contribution illustrates the shift towards a more socially oriented model of state aid control. It is not entirely evident whether the drivers of such a shift have been the constitutional innovations brought by the Treaty of Lisbon and the aspirational objective of making the EU a 'social market economy' that strives towards 'social justice'. However, this shift does not represent a merely temporal and pragmatic response to the 'constitutional malaise' that the EU is experiencing, nor a response to the economic crisis. Rather, it shows a distinct attempt to mainstream social goals into state aid control.

\footnotetext{
116 M Blauberger, From Negative to Positive Integration. European State Aid Control through Soft and Hard Law (paper to be presented at EUSA Eleventh Biennial International Conference, 2009), http://aei. pitt.edu/33031/1/blauberger._michael.pdf.

117 Delors outlined the main tenets of the EU Social Dimension in his famous address to the Trade Union Congress in Bournemouth, 8 September 1988.
} 